\title{
The Costs of Quality: An Important Decision Tool
}

\author{
Victoria Firescu ${ }^{1}$, Jenica Popescu ${ }^{2}$
}

\begin{abstract}
:
At present many company leaders of assimilate the insurance of quality with a rule imposed from the outside and with an administrative act, which is an error. The biggest impediment in implementing the systems of quality insurance is the fact that producers do not acknowledge its economic advantages. Quality is seen as a desired social objective but its contributions to the profit of the company are considered to be marginal.

This paper aims to putting into emphasis the total interdependence between the concept regarding the quality insurance and the commercial success, redefining in economic terms the objectives and the actions necessary for the implementation of the system of quality insurance. The production of quality products is not something sufficient. The costs of realizing the objectives must be carefully observed, so that the long term effect of the quality costs within the company be the desired one.

That is why it is important that the efficiency of a system of quality be measured in economic terms. The costs of quality do not distinguish themselves from the other types of costs. Just as the costs for maintenance, projection, production, sale and other activities, they can be measured and analyzed in the stages of the product's life cycle, as well as in all the operational levels of the company.
\end{abstract}

Keywords: cost of quality, quality insurance, prevention costs

JEL Classification: D24, L15

\footnotetext{
${ }^{1}$ Assoc. Prof. Ph. D., University of Piteşti, Faculty of Economic Sciences, B-dul Republicii, Nr.71, Piteşti, Romania; email: firescuvictoria@yahoo.com

${ }^{2}$ Prof. Ph.D., University of Craiova, Faculty of Economics and Business Administration, A.I.Cuza Street, no. 13, postal code 200585, Craiova, Dolj, Romania
} 


\section{Introduction}

Quality costs are not different from the other types of costs. Much like the maintenance, project, production, sale costs and the costs of other activities, they too can be measured and analysed.Quality costs appear in each of the stages of the product life cycle, as well as at all the operational levels of the company.Traditionally, poor-quality costs are correlated with scrapped goods, rework, excessive effort spent on tests and trials. These costs are easily understandable but little reference is made to them in the account books of the company. Moreover, the poor management of quality costs leads to other costs that could be avoided.

Nowadays, several studies reveal that the non-quality costs as well as the prevention and appraisal costs amount to an average of $25 \%$ of the turnover of a company and to approximately $5-15 \%$ of the production cost. In Crosby's opinion, they would amount to a much higher percentage, up to $40 \%$ in the case of the service companies. The level of the quality costs represents an important instrument of quality valuation, a potential source of increasing the profit of the company. There is a possibility of identifying the ineffective activities and the critical points of the processes through costs thus providing a more reliable basis for corrective or improvement actions necessary in a certain sector of the company and the evaluation and monitoring of the effectiveness dynamics of the adopted measures. However, they do not represent an absolute measure of the performance of a company. They must be appropriately integrated into the management performance evaluation system.

\section{Quality Costs and Conceptual Approaches}

Quality costs represent one of the main topics debated in the specialized literature, being an important instrument that allows for the financial evaluation of the measures adopted in order to ensure performance. In his paper "Quality Control Handbook", Juran widely approaches the problems of quality costs, specifying that 11 categories of costs are necessary for the manufacture of products "fit for use".

In his approach of quality costs problems, Feigenbaum considers that four categories of costs are needed: prevention costs, appraisal and control costs, internal defect costs and external defect costs. Internal defects are defined as defects identified before the product delivery, while external defects are defects identified after the product shipment to the receivers (traders, dealers, customers).

In Crosby's opinion, quality is free, and he approaches quality exclusively through two categories of "prices": the price of conformance and the price on nonconformance. He prefers the word "price" instead of "cost", in order to highlight the fact that this price that is paid is not unavoidable; in fact, on the contrary, it can be reduced and even eliminated. He includes into the price of conformance all the expenses necessary to provide the product conformance with the requirements and 
into that of the non-conformance, the expenses incurred because the product is not in conformance with these requirements.

Kelada criticizes the traditional approach of quality costs, mainly because it only takes into consideration direct, tangible costs, and proposes the following distinct categories of costs:

- $\quad$ direct quality costs that are quantifiable and non-quantifiable;

- indirect quality costs that are, in their turn, also subdivided into quantifiable;

- non-quantifiable costs.

According to Tkaczyk, S. (2001) quality costs represent the main indicators on the basis of which the performance of the quality management systems can be evaluated. Quality cost $\left(\mathrm{c}_{\mathrm{c}}\right)$ could be defined (Rusu, C. and others, 2001) as the difference between the actual cost $\left(c_{R}\right)$ of a product or service and its reduced cost $\left(c_{r}\right)$ if no service below standards and no failure or manufacturing defect would have occurred into the product manufacture.

According to international standard ISO 8402, quality costs represent the costs incurred to ensure the quality level of the products and services as well as the losses that occur when the satisfactory level of quality is not reached. To summarize, a typology of these costs can be made (Rusu, C. and others, 2001) so that they could be analyzed in the clearest possible way (figure 1). This typology is established by norm AFNOR X50-126 France. Nevertheless, this is not the only typology available on the market. Inspiring himself from Juran's and Deming's papers, Harrington proposes a slightly different approach (an approach adopted by ASQC) where we can find the same categories of costs.

Figure 1. Typology of quality costs (Rusu, C. and others, 2001)

$N Q C$ - non-quality costs; $Q C$ - quality costs/costs necessary to achieve quality

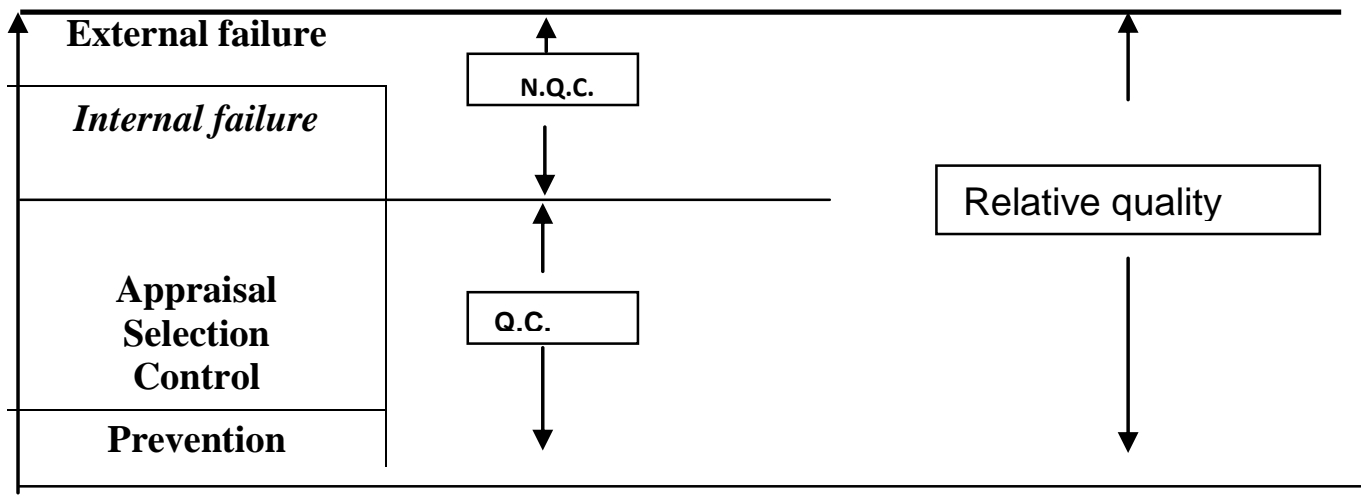




\section{Practical Approaches of Quality Costs}

Currently, the classic approach of quality costs, with its delimitation of the four categories of costs (prevention, appraisal, internal and external failure), is the most unanimously accepted one in the specialized literature, and especially in the economic practice. The European Organization for Quality -EOQ defines quality costs as costs representing "the costs implied by the prevention and appraisal activities and by the loss caused by the internal and external failure".

The German Society for Management Systems (Deutsche Gessellschaft fur Managementsystemen) gives a similar definition: "quality costs represent the costs implied by the measures adopted in order to prevent defects, the quality appraisal and the internal and external failures ". For a more convincing suggestion that these costs are avoidable, and that in fact, quality "is free", the usage of the expression "quality-related costs" instead of "quality costs" have been established lately. The new expression was also accepted in the 1994 amended version of the ISO 9000 family of standards.

Prevention costs represent the costs incurred with the efforts made to prevent the occurrence of defects. Costs implying the following are part of this category:

- product and process engineering;

- drawing up the quality management system and the quality system documents (quality planning, quality manual, quality system procedures, etc.);

- quality improvement programme;

- employee quality awareness and training;

- supplier evaluation;

- a comparative analysis of the quality of the company with that of the competitors;

- quality audit;

- process control (for example, by applying the statistical control methods);

- calibration of equipment;

- quality system implementation;

- other quality assurance measures.

The appraisal costs represent the costs incurred with tests inspections and checks performed to determine whether the specified requirements are met. A more suggestive definition of these costs is given by Vachette: "the appraisal costs represent all the costs incurred so that a non-conform product should not reach its internal of external client". This category comprises costs implying: inspections and tests of purchased materials and products, in-process inspections and tests, finished product acceptance, test equipment purchase and maintenance, laboratory tests, 
inspection and test documentation, inspection and test employees' wages, analysis of the inspection and test results, materials and products destroyed during tests.

The internal failure costs represent the costs incurred to correct all the nonconformities found prior to the product supply to the beneficiary. The costs determined by the following fall into this category:

- the volume of scrap;

- $\quad$ performing remedy, rework and repair operations;

- costs of reprocessing, re-treatment, repeating the tests;

- $\quad$ product downgrading costs;

- failure analysis, with the purpose of finding the cause;

- idle time (for example, downtime);

- non-conformance of raw material that was not found at its acceptance; additional operations to sort components in order to eliminate the nonconform ones.

The external failure costs represent the costs incurred for the remedy of the nonconformities found after the product supply to the beneficiaries. The costs determined by the following fall into this category:

- customer complains;

- customer returns;

- $\quad$ product liability insurance premiums paid by the companies;

- damages;

- $\quad$ penalties for delays in deliveries;

- providing service and after-service;

- warranty replacements.

By definition, failure costs are caused by the non-conformance of products to the specifications, so they only represent material loss, but lately, there is an everincreasing tendency of taking into account the immaterial losses even if they are more difficult to quantify.

\section{Monitoring Quality Costs by Means of Key Performance Indicators}

Monitoring quality costs is an essential prerequisite for the introduction of an efficient quality management system. They represent an important instrument for the improvement of the quality and efficiency of the organization because they are the fundament of the strategic decision-and have a direct influence on the profit size. For the evaluation of the performance of the quality management systems, a system of quantitative indicators based on quality costs and on the economic and financial results of the company should be developed. A comparative analysis of the main models of evaluating the performance of quality management systems is presented in Table 1. 
Table 1. Comparative analysis of the models of evaluating the performance of quality management systems

\begin{tabular}{|c|c|c|c|c|c|c|c|c|}
\hline $\begin{array}{l}\text { It. } \\
\text { No. }\end{array}$ & Aspects & $\begin{array}{l}\text { Deming } \\
\text { Model }\end{array}$ & \multicolumn{2}{|c|}{ M. Baldrige Model } & \multicolumn{2}{|c|}{ EFQA Model } & \multicolumn{2}{|c|}{ Juran Model } \\
\hline- & $\begin{array}{l}\text { Purpose of } \\
\text { developm } \\
\text { ent }\end{array}$ & $\begin{array}{l}\text { Japanese } \\
\text { industrial } \\
\text { reorientation } \\
\text { towards } \\
\text { quality }\end{array}$ & \multicolumn{2}{|c|}{$\begin{array}{l}\text { Recognition of the } \\
\text { American } \\
\text { organizations with } \\
\text { outstanding quality } \\
\text { management } \\
\text { achievements }\end{array}$} & \multicolumn{2}{|c|}{$\begin{array}{l}\text { The orientation of } \\
\text { European } \\
\text { organizations } \\
\text { towards } \\
\text { excellence } \\
\text { sustainable by the } \\
\text { systematic } \\
\text { identification and } \\
\text { promotion of the } \\
\text { best practices }\end{array}$} & \multicolumn{2}{|c|}{$\begin{array}{l}\text { Promoting } \\
\text { the Romanian } \\
\text { organization } \\
\text { competitivene } \\
\text { ss } \\
\text { through } \\
\text { quality }\end{array}$} \\
\hline- & $\begin{array}{l}\text { Common } \\
\text { objective }\end{array}$ & \multicolumn{7}{|c|}{ Continuous organization performance improvement } \\
\hline- & $\begin{array}{l}\text { Accessibil } \\
\text { ity degree }\end{array}$ & \multicolumn{2}{|l|}{ Limited } & \multicolumn{2}{|l|}{ High } & \multicolumn{2}{|l|}{ High } & High \\
\hline- & $\begin{array}{l}\text { Conforma } \\
\text { nce with a } \\
\text { certain } \\
\text { model }\end{array}$ & \multicolumn{2}{|c|}{$\begin{array}{l}\text { It does not require } \\
\text { that candidates } \\
\text { should conform to } \\
\text { a certain model }\end{array}$} & \multicolumn{2}{|c|}{$\begin{array}{lr}\text { It requires } & \text { that } \\
\text { candidates } & \text { should } \\
\text { conform to a certain } \\
\text { model }\end{array}$} & \multicolumn{2}{|c|}{$\begin{array}{l}\text { It requires that } \\
\text { candidates } \\
\text { should conform } \\
\text { to a certain } \\
\text { model }\end{array}$} & $\begin{array}{l}\text { It } \\
\text { requires } \\
\text { that } \\
\text { candidat } \\
\text { es } \\
\text { should } \\
\text { conform } \\
\text { to a } \\
\text { certain } \\
\text { model } \\
\end{array}$ \\
\hline- & $\begin{array}{l}\text { Model } \\
\text { type }\end{array}$ & \multicolumn{2}{|c|}{$\begin{array}{l}\text { Two-dimensional: } \\
\text { TQM bases ; TQM } \\
\text { purposes }\end{array}$} & \multicolumn{2}{|c|}{\begin{tabular}{lr}
\multicolumn{2}{l}{ Three-dimensional: } \\
strategy and action \\
plans; & system; \\
information & and \\
analysis &
\end{tabular}} & \multicolumn{2}{|c|}{$\begin{array}{l}\text { Two- } \\
\text { dimensional: } \\
\text { determining } \\
\text { factors; results }\end{array}$} & $\begin{array}{l}\text { Two- } \\
\text { dimensi } \\
\text { onal: } \\
\text { determi } \\
\text { ning } \\
\text { factors; } \\
\text { results }\end{array}$ \\
\hline- & $\begin{array}{l}\text { Number of } \\
\text { criteria }\end{array}$ & \multicolumn{2}{|l|}{10} & \multicolumn{2}{|l|}{7} & \multicolumn{2}{|l|}{9} & 9 \\
\hline- & $\begin{array}{l}\text { Criteria } \\
\text { quantificat } \\
\text { ion }\end{array}$ & \multicolumn{2}{|c|}{$\begin{array}{l}\text { It is not } \\
\text { standardized but } \\
\text { depends on the } \\
\text { importance, extent } \\
\text { and role of each } \\
\text { criterion }\end{array}$} & \multicolumn{2}{|l|}{ Definite } & \multicolumn{2}{|l|}{ Definite } & Definite \\
\hline- & $\begin{array}{l}\text { Orientatio } \\
\mathrm{n} \text { towards } \\
\text { clients }\end{array}$ & \multicolumn{2}{|c|}{$\begin{array}{l}\text { A very important } \\
\text { objective. } \\
\text { (undefined } \\
\text { percentage) }\end{array}$} & \multicolumn{2}{|c|}{$\begin{array}{l}\text { A relatively high } \\
\text { orientation towards } \\
\text { clients as compared } \\
\text { to the orientation } \\
\text { towards the other }\end{array}$} & \multicolumn{2}{|c|}{$\begin{array}{l}\text { Strong emphasis } \\
(200 \text { points out } \\
\text { of } 1000 \text { possible } \\
\text { points) }\end{array}$} & $\begin{array}{l}\text { Strong } \\
\text { emphasi } \\
\text { s }(200 \\
\text { points } \\
\text { out of }\end{array}$ \\
\hline
\end{tabular}




\begin{tabular}{|c|c|c|c|c|c|}
\hline & & & $\begin{array}{l}\text { business results }(210 \\
\text { points) }\end{array}$ & & $\begin{array}{l}1000 \\
\text { possible } \\
\text { points) }\end{array}$ \\
\hline- & $\begin{array}{l}\text { Orientatio } \\
\mathrm{n} \text { towards } \\
\text { the } \\
\text { business } \\
\text { results }\end{array}$ & & $\begin{array}{l}\text { Very strong emphasis } \\
(325 \text { points out of } \\
1000 \text { possible points })\end{array}$ & $\begin{array}{l}\text { A lower } \\
\text { emphasis than } \\
\text { the one of client } \\
\text { satisfaction (150 } \\
\text { points out of } \\
1000 \text { possible } \\
\text { points) }\end{array}$ & $\begin{array}{l}\text { A lower } \\
\text { emphasi } \\
\mathrm{s} \text { than } \\
\text { the one } \\
\text { of client } \\
\text { satisfact } \\
\text { ion (150 } \\
\text { points } \\
\text { out of } \\
1000 \\
\text { possible } \\
\text { points) }\end{array}$ \\
\hline - & $\begin{array}{l}\text { Dependen } \\
\text { ce on } \\
\text { Benchmar } \\
\text { king }\end{array}$ & Less dependent & Dependent & $\begin{array}{l}\text { Relatively strong } \\
\text { emphasis }\end{array}$ & $\begin{array}{l}\text { Compul } \\
\text { sory }\end{array}$ \\
\hline- & Feedback & $\begin{array}{l}\text { The evaluation } \\
\text { report is only given } \\
\text { to qualified } \\
\text { candidates }\end{array}$ & $\begin{array}{l}\text { The evaluation report } \\
\text { is given to all the } \\
\text { organizations taking } \\
\text { part into the } \\
\text { competition }\end{array}$ & $\begin{array}{l}\text { The evaluation } \\
\text { report is given to } \\
\text { all the } \\
\text { organizations } \\
\text { taking part into } \\
\text { the competition }\end{array}$ & $\begin{array}{l}\text { The } \\
\text { evaluati } \\
\text { on } \\
\text { report is } \\
\text { given to } \\
\text { all the } \\
\text { organiza } \\
\text { tions } \\
\text { taking } \\
\text { part into } \\
\text { the } \\
\text { competi } \\
\text { tion }\end{array}$ \\
\hline
\end{tabular}

Source: www.efqm.org, www.quality.nist.gov, www.asq.org

Table 2. Performance indicators structured with the help of quality costs in Romanian companies

\begin{tabular}{|c|c|}
\hline $\begin{array}{c}\text { It. } \\
\text { No }\end{array}$ & Designation \\
\hline 1. & Customer returns, expressed in physical terms (units/100 sold products). \\
\hline 2. & Customer returns, expressed in financial terms, (lei / turnover of 1000 lei). \\
\hline 3. & $\begin{array}{l}\text { Repairs performed on in-warranty products, expressed in physical terms (no. of units / } \\
100 \text { sold products) }\end{array}$ \\
\hline 4. & Downtime expressed in financial terms (lei/ production costs of 1000 lei) \\
\hline 5. & $\begin{array}{l}\text { Cost due to unusable supply expressed in financial terms (lei/ production costs of } \\
\text { 1000 lei) }\end{array}$ \\
\hline 6. & Product downgrading costs (products the price of which was reduced as a result of \\
\hline
\end{tabular}




\begin{tabular}{|c|c|}
\hline & $\begin{array}{l}\text { their non-conformance with the customers' requirements or due to an excessive } \\
\text { quantity of manufactured products (cost of the downgraded product in lei / } \\
\text { production costs of } 1000 \text { lei) }\end{array}$ \\
\hline 7. & $\begin{array}{l}\text { Repairs performed on in-warranty products, expressed in financial terms (lei / a } \\
\text { turnover of 1000) }\end{array}$ \\
\hline 8. & Inspection activities expressed in physical terms (min / shift). \\
\hline 9. & Client losses expressed in financial terms (loss in lei / a turnover of 1000 lei) \\
\hline 10. & $\begin{array}{l}\text { Inspection activities expressed in financial terms (inspection costs in lei / production } \\
\text { costs of } 1000 \text { lei). }\end{array}$ \\
\hline 11. & Scrap expressed in physical terms (units/100 manufactured products) \\
\hline 12. & $\begin{array}{l}\text { Marketing and research related costs (marketing and research related costs in lei / } \\
\text { total costs of } 1000 \text { lei) }\end{array}$ \\
\hline 13. & Scrap expressed in financial terms (lei / production costs of 1000 lei) \\
\hline 14. & $\begin{array}{l}\text { Costs related to audits to suppliers (costs related to audits to suppliers in lei. / total } \\
\text { costs of } 1000 \text { lei) }\end{array}$ \\
\hline 15. & $\begin{array}{l}\text { Rework of defective products expressed in physical terms (units/100 manufactured } \\
\text { products) }\end{array}$ \\
\hline 16. & Employee training costs (employee training costs in lei / total costs of 1000 lei) \\
\hline 17. & $\begin{array}{l}\text { Rework of defective products expressed in financial terms (lei / production costs } \\
\text { of } 1000 \text { lei) }\end{array}$ \\
\hline 18. & $\begin{array}{l}\text { Insurance premium related costs (insurance premium related costs in lei / total } \\
\text { costs of } 1000 \text { lei) }\end{array}$ \\
\hline 19. & 1 terms (ex.: $\mathrm{min} / \mathrm{shift})$. \\
\hline
\end{tabular}

One can notice that the vast majority of indicators are constituted on the basis of the internal failure related costs (scrap, unusable supply costs). This fact proves once again that Romanian companies are focused on eliminating the found failures, which is characteristic of quality control systems, and are less focused on their prevention through the identification and elimination of their root causes (which is characteristic of modern quality management systems).

\section{References}

Avasilcăi, S., (2001). Organizational Performance Management, Tehnopress Publishing House, Iaşi.

Břečková, P. and Havlíček, K. (2013). Leaders Management and Personnel Controlling in SMEs. European Research Studies Journal, 16 (4), Special Issue on SMEs.

Capotă , A., (1997). Costul calităţii şi urmărirea lui în contabilitatea de gestiune, Tribuna Calităţii nr6, 7.

Havlíček, K., Thalassinos I.E. and Berezkinova, L. (2013). Innovation Management and Controlling in SMEs. European Research Studies Journal, 16(4), 57-70, Special Issue on SMEs.

Kélada, J., (1990). La gestion intégrale de la qualité, sur une qualité totale, Edition Quafec, Quebéc.

Lupu, L., Rusu, C., Reteacă, C., Negurici, O., Rusu, B., Condurache, G. (2003). Analysis of 
the Production Processes for Increasing work Productivity within a chemical Enterprise - case study, Proceedings of the $3^{\text {rd }}$ International Conference in Management of Technological Changes, vol. II, Technical University of Crete, Greece.

Negurici, O., Rusu, C. (2003). The Impact of TQM Implementation in Technological Changes, Proceedings of the $3^{\text {rd }}$ International Conference in Management of Technological Changes, vol. II, Technical University of Crete, Greece.

Negurici, O., Rusu, C. (2002). Managementul calităţii în Întreprinderile de Confecţii din România, Publishing House Perfomantica, Iaşi. 